\title{
COMMUNICATION FOR BUSINESS AND SECRETARIAL STUDENTS
}




\title{
Communication
}

for Business and

Secretarial Students

\author{
Lysbeth A. Woolcott, B.A. \\ Lecturer in English and Communication \\ East Berks College, Maidenhead \\ Wendy R. Unwin, B.A. \\ Lecturer in Educational Technology \\ East Berks College, Maidenhead
}

\section{Macmillan Education}


(C) Lysbeth A. Woolcott and Wendy R. Unwin 1974

All rights reserved. No part of this publication may be reproduced or transmitted, in any form or by any means, without permission.

First published 1974 by

THE MACMILLAN PRESS LTD

London and Basingstoke

Associated companies in New York Dublin

Melbourne Johannesburg and Madras

SBN 333148673

ISBN 978-0-333-26175-0 ISBN 978-1-349-04530-3 (eBook)

DOI 10.1007/978-1-349-04530-3

Typeset by

Computatype (UK) LTD.

Fort William 


\section{CONTENTS}

Preface vii

Acknowledgements viii

List of Illustrations ix

1 Principles of Good Communication 1

The media; use of language; choice of vocabulary; communication in business; communication failures; channels of communication; barriers to communication; the role of the secretary; suggested approach to an examination question

2 USE OF ENGLISH

Grammar; punctuation; spelling

3 EsSaYs

Preparation; writing; examination requirements; essay plans

4 LetTer WRITING

Layout; content; style, vocabulary and tone; types of business letters

5 RePorts AND MEMORANDA

Reports and memoranda; informal reports; formal reports

6 SumMARISING

General considerations; technical problems; method; summarising correspondence

7 COMPREHENSION

Method; advice; types of question

8 Miscellany

Press releases; advertising; forms; telegrams and telex

9 Meetings and Committees

Definition of committees; purposes of meetings; advantages and disadvantages; types of meetings; procedure; the roles of chairman, secretary and members 
10 Mentings - Arrangements and Documents

Date, time and venue; notice of meetings; agenda; chairman's agenda; minutes

11 Oral Communication

Speech; words; barriers; a logical approach; telephone techniques; messages

12 INTERVIEWS

The paper work; the interviewer; the interview; assessment; the candidate; examination orals; facing the panel

13 Visual Communication

Tables; types of charts and graphs; visual control boards; the use of charts and graphs

14 The Place of Communication

Language; structure; attitudes; choice; feedback

15 LONGER EXERCISES

Eight complex exercises using a variety of means of communication

16 APPENDICES

1. Skip test answers

2. Extracts from the Memorandum and Articles of Association of a Limited Liability Company

3. Glossary of terms in relation to meetings

4. Telephone script errors

5. The story behind 'The Move' 


\section{PREFACE}

This book is primarily intended for secretaries and would-be secretaries studying for examinations such as those of the London Chamber of Commerce, the Royal Society of Arts and the Scottish Business Education Council The information will also be useful to students on other courses such as the Ordinary National Certificate and Diploma in Business Studies and the Department of Employment Training Opportunities Scheme.

The exercises in the book are intentionally broadly based and follow the authors' purpose in bringing together aspects of the study of communication which are tested in different examination papers, many of which do not bear the title 'Communication'. The book also offers guidance for use in practical office situations. For these reasons students will need specific knowledge which may be gained from a closer examination of the subject, a degree of common sense and initiative when applying broad principles to particular situations and the ability to apply knowledge of other disciplines.

July 1974

L. A. W. W. R. U. 


\section{ACKNOWLEDGEMENTS}

The authors wish to thank Mrs M. Tucker, Mr E. Evans, Mr D. Sanders and the many colleagues and friends whose advice and help have been so generously given.

Grateful acknowledgement is made to the following for permission to reprint material:

Extract from The Population Bomb, revised edition, by Dr. Paul R. Ehrlich, copyright (C) Paul R. Ehrlich 1968, 1971, reprinted by permission of Ballantine Books Inc., Division of Random House Inc.; Consumers' Association for extracts from a report 'Shoddy Goods and the Law' from Which?, June 1973; Hamish Hamilton Ltd for an extract from Usage and Abusage by Eric Partridge, Hamish Hamilton Ltd, London, 1947; William Heinemann Ltd for diagrams from Business Statistics by W. J. Bell and J. L. Mather; Help the Aged for use of Figure 28, p. 144; the Controller of Her Majesty's Stationery Office for extracts from Report of the Royal Commission on Local Government, Cmnd 4040, Economic Progress Reports, Local Employment Act 1960, First Annual Report by the Board of Trade and Trade and Industry; Hutchinson Publishing Group Ltd for an extract from The State and the Citizen by J. D. Mabbott; Michael Joseph Ltd for an extract from The Shocking History of Advertising by E. S. Turner; the London Chamber of Commerce and Industry for questions from examination papers; Longman Group Ltd for an extract from The Geography of Economics by O. G. Parker; Management Publications Ltd for extracts from 'Flexible Time-Clock' and 'Managers versus Entrepreneurs' from Management Today; John Murray (Publishers) Ltd for an extract from Parkinson's Law by Northcote Parkinson; New Science Publications for 'The Language of Clothes' by Keith Gibbins, which first appeared in New Society, 4 June 1970, and an extract from New Society, 1 February 1973; The Observer Ltd for extracts from The Observer; Penguin Books Ltd for use of extracts from Geography of World Affairs, pp. 242-3, by J. P. Cole, copyright (C) J. P. Cole 1959, 1963, 1965, Language in Modern World, pp. 162-3, copyright (C) Simeon Potter 1960, Britain in Figures, p. 19, copyright (C) Alan F. Sillitoe 1971, The Economics of Everyday Life, p. 39, copyright (C) Gertrude Williams 1950, 1964; Pitman Publishing Ltd, London, for an extract from The Business Executive by H. R. Light; Royal Society of Arts for extracts from R.S.A. Examination Papers; the Scottish Business Education Council for extracts from SCOTBEC Advanced Secretarial Certificate; R. Stevens, An Approach to Literature; Top Secretary for an extract from Top Secretary, November 1973; Derick Unwin for an article by K. Austwick from Media and Methods.

The publishers have made every effort to trace the copyright-holders, but if they have inadvertently overlooked any they will be pleased to make the necessary arrangement at the first opportunity. 


\section{LIST OF ILLUSTRATIONS}

Figure 1 Semi-blocked letter $\quad 36$

2 Fully-blocked letter 37

3 Faulty letter (a) 43

4 Faulty letter (b) 44

5 Faulty letter (c) 44

6 Faulty letter (d) 44

7 Faulty letter (e) 45

8 Faulty letter (f) 45

9 A sales letter 47

10 Letter of complaint 48

11 Letter of adjustment 49

12 Tact 50

13 Letter of application 53

14 Exercise 1 54

15 Memoranda forms 62

16 A formal memorandum 63

17 Layout of an informal report 66

18 Sample contents page $\quad 67$

19 How to write a summary 86

20 Summarising correspondence (a) 92

21 Summarising correspondence (b) 93

22 Summarising correspondence (c) 93-4

23 Summarising correspondence (d) 94

24 Summarising correspondence (e) 95

25 Summarising correspondence (f) 95

26 Crude birth rate, at two-year intervals: U.K. 135

27 Display advertisement (a) 143

28 Display advertisement (b) 144

29 Application form 147

30 Completed application form 148

31 Letter to be condensed to telegram 149

32 The Board of Noah's Ark Limited meets 160

33 Notice of meeting 165

34 Agenda 167

35 Notice of meeting and agenda 168

36 Chairman's agenda 168

37 Minutes 175

38 Exercise 1 - agenda 177

39 Job advertisements 192

40 Interview assessment form 196 
$\mathbf{x}$

\section{List of Illustrations}

Figure 41 Table - industrial production $\quad 212$

42 Graph - industrial production $\quad 212$

43 Complex table 213

44 Pictogram 214

45 Statistical map $\quad 215$

46 Diagram 215

47 Flow sheet 216

48 Organisation chart 218

49 Pie charts 219

50 Line graphs 219

51 Line graph with dual scale 220

52 Complex line graph 221

53 Bar chart 222

54 Complex bar charts $\quad 222$

55 Dual information chart 223

56 Histogram 224

57 Frequency polygon 224

58 Gantt chart 225

59 'Z' chart 225

60 Exercise $11 \quad 229$

61 Exercise 7 - organisation chart 249

62 Exercise 7 - staffing 250

63 Exercise 7 - memorandum 250 